\title{
Izbrisani slovarski sestavki iz druge, dopolnjene in deloma prenovljene izdaje Slovarja slovenskega knjižnega jezika
}

Iz druge, dopolnjene in deloma prenovljene izdaje Slovarja slovenskega knjižnega jezika smo morali zaradi zahteve imetnikov blagovnih znamk Cockta, Superga, Teflon in Tetra Pak po drugačni slovarski obravnavi umakniti slovarske sestavke, ki prikazujejo iz navedenih blagovnih znamk izpeljane občnoimenske besede.

Imetniki blagovnih znamk so svojo zahtevo utemeljili na Zakonu o industrijski lastnini (Uradni list Republike Slovenije 51/2006), ki v 51. členu pravi takole: »Če daje reprodukcija znamke v slovarju, enciklopediji ali podobnem delu vtis, da gre za generično ime blaga ali storitev, za katere je znak registriran, mora založnik dela na zahtevo imetnika znamke poskrbeti za to, da je najkasneje v naslednji izdaji publikacije pri reprodukciji znamke oznaka, da gre za znamko.«

Sklicujoč se na to zakonsko določilo, so imetniki navedenih blagovnih znamk zahtevali zapis iztočnice z veliko začetnico in znakom ${ }^{\circledR}$, slovarske razlage pa so si celo prizadevali spremeniti v ozke terminološke definicije. Uresničitev teh zahtev bi nasprotovala slovarskemu konceptu, izkazani jezikovni rabi in predvsem strokovnim slovaropisnim načelom, zato smo sporne sestavke raje umaknili iz slovarja. Namesto v slovarju jih brez pravnih zadržkov objavljamo v znanstveni reviji, s čimer želimo informirati jezikovne uporabnike o pisanju imen teh blagovnih znamk in o splošni rabi iz njih izpeljanih občnoimenskih besed, predvsem pa v okviru znanstvenega diskurza spodbuditi nadaljnje strokovne razprave o tej pravno zanimivi in jezikoslovno pereči problematiki.

cockta in kókta -e [kókta] ž (ộ) osvežujoča gazirana brezalkoholna pijača znamke Cockta: piti cockto; steklenica cockte

kokta gl. cockta

supêrga -e ž (ê) nav. mn., pog. športni copat: obuti superge; trenirka in superge

teflón -a m (ộ) umetna snov znamke Teflon, odporna proti kemikalijam in višjim temperaturam: prevleči posodo s teflonom teflónski -a -o prid. (ộ) 1. nanašajoč se na teflon: teflonska prevleka / teflonska ponev, posoda 2 . ekspr. neobčutljiv za kritiko, očitke: teflonski politik

tétrapak tudi tetrapák -a m (ệ; â) embalaža podjetja Tetra Pak za tekočine, navadno iz močnejšega, plastificiranega papirja: izdelovati tetrapak / mleko, sok v tetrapaku; v prid. rabi: tetrapak embalaža

Nataša Gliha Komac-Nataša Jakop-Boris Kern-Simona Klemenčič - Domen Krvina - Nina Ledinek-Mija Michelizza-Tanja Mirtič-Andrej Perdih-Špela Petric-Marko Snoj-Andreja Žele 